KLEMEN KAVČIČ, Ph.D. ${ }^{1}$

(Corresponding author)

E-mail: klemen.kavcic@fm-kp.si

JANA SUKLAN, Ph.D. ${ }^{2}$

E-mail: jana.suklan@fuds.si

FRANKO MILOST, Ph.D. ${ }^{1}$

E-mail: franko.milost@fm-kp.si

1 University of Primorska, Faculty of Management

Cankarjeva 5, 6101 Koper, Slovenia

2 School of Advanced Social Studies in Nova Gorica

Gregorčičeva 19, 5000 Nova Gorica, Slovenia
Transport Logistics

Preliminary Communication

Submitted: Jan. 10, 2016

Accepted: Sep. 21, 2016

\title{
OUTSOURCING LOGISTICS ACTIVITIES: EVIDENCE FROM SLOVENIA
}

\begin{abstract}
The purpose of this research is to investigate how logistics outsourcing performs activities that have been traditionally carried out within the outsourcer's company. The study examines the characteristics of logistics and transport services, which are important in cooperation with service providers. Two groups were formed according to the average values of the characteristics of logistics activities. 'Cost, quality and response' are important for the first group, while 'logistics, environment and the ability to adapt to client processes' are important for the second group. The results of the survey carried out in Slovenian enterprises show that both groups are primarily interested in express freight and shipment services, the difference lying in the understanding of logistics, mutual trust and brand recognition. The findings will be useful both in business practice and for managers, providing them with a better understanding of the performance of logistics outsourcing.
\end{abstract}

\section{KEY WORDS}

logistics outsourcing; third-party logistics; supply chain;

\section{INTRODUCTION}

The amount of scientific literature regarding outsourcing is growing rapidly; however, despite this growth, little attention has been paid to how the characteristics of the logistics service markets change the logistics outsourcing and enterprise performance.

Service outsourcing literature indicates that outsourcing performance should not only be assessed in terms of cost reduction for the outsourcer, but also in terms of added benefits, such as improved margins for the outsourcing service provider, as well as improved service and innovation [1, 2].

Outsourcing is one method of managing enterprise complexity, from 'hierarchy' to the 'marketplace'. 'Hierarchy' represents management with the power of ownership, while 'marketplace' comprises management with the power of influential stakeholder interest. Influential stakeholders align their interest promptly on the 'marketplace', and usually conclude short-term agreements, whereas relationships in a 'hierarchy' tend to be more sustainable and robust.

Third-party logistics (3PL) now plays a crucial role in many supply chains. With the growing trend of outsourcing, many organizations have outsourced their logistics activities to 3PL providers to focus on their core competencies, which reduces operating costs and improves the service level [3]. Since many 3PL providers have already been orchestrating their clients' supply chains [4], they are in an advantageous position to synergize a procurement service for value creation.

For example, 3PL enterprises are playing ever-increasing roles in extended supply chains, transforming themselves from movers of goods to strategic value-added entities. Similarly, there has been an expansion in the scope of services offered by 3PL firms through the inclusion of recent value-added functions, such as after-sales support, customer service and reverse logistics.

In the annual 3PL report, Langley [5] stated that traditionally third-party logistics (3PLs) have relied on relationship-based selling, which frequently depended upon personal connections and customized solutions to meet the clients' needs. However, in today's contemporary world of logistics, these time-honoured approaches no longer suffice. As 3PL operations become more complex, clients are becoming more sophisticated and structured in the ways they conduct business. Today's 3PL business development and operations teams are seeking new, improved and innovative ways to create value for their clients.

By turning to external operators in their activities, enterprises can mobilise resources, knowledge and, most importantly, gain a competitive advantage. This paper examines the characteristics of the logistics services and IT solutions markets, assigning additional meaning and value to logistics providers based on client views in terms of potential business cooperation, which were identified through a survey. 
The remainder of the paper is organized as follows: Section 2 provides a theoretical background and literature review, while the research methodology, data collection method used and results are described in Section 3. A discussion and conclusion are presented in Section 4, with suggested topics for future research.

\section{THEORETICAL BACKGROUND}

Third-party logistics (3PL) plays an important role in many supply chains nowadays. In its Outsourcing Annual Report for the Year 2013, data analytics company Ernst \& Young [6] concluded that the outsourcing segment would continue to grow steadily. Cooperation between respondents from eight participating countries provided the feedback that enterprises, on the average, expect and forecast outsourcing to grow by approximately $31.4 \%$.

Given the current interest in and emphasis on risk management, most 3PLs are focusing on developing new products and services to create value for their clients. This seems to be the key area for collaboration between 3PLs and their customers. In the interest of determining the value derived from risk management processes, it would be useful to better understand the roles that 3PLs play in partnerships with their clients in identifying and mitigating, eliminating or managing risks that could affect the overall supply chain process [7].

The 3PL market has become increasingly competitive. The leading 3PL providers have been continually developing new value-added services to differentiate themselves from their competitors. Procurement outsourcing has been a growing sector since the early 2000s. The 3PL providers are in the advantageous position of being able to offer their own procurement outsourcing service, i.e. 3rd-party (logistics) providers. However, few 3PL providers have grasped this opportunity [7].

According to the authors [8-10], outsourcing can be classified as three types:

1) Basic - low-level value-added logistics services, such as transportation, warehousing and delivery services.

2) Customized - special logistics requirements, such as the express delivery of documents, components and consolidation; this requires tangible resources, such as informational processing and decision-support systems, and intangible resources such as professional knowledge and specific programmes.

3) Advanced - strategic decisions for the entire supply chain; this includes order processing, packaging, labelling, and the improvement and optimization of logistics information systems.

Again, as in study [11], the most frequently outsourced activities tend to be those that are more transactional, operational and repetitive in nature. Activities that are strategic, IT-intensive and client-oriented tend to be outsourced to a lesser extent. These include domestic and international transportation (80\% and $70 \%$, respectively), warehousing (67\%), customs brokerage (53\%) and freight forwarding (51\%). With the exception of domestic transportation, these percentages are several points lower than those reported in the previous study [11]. However, there is some indication that those activities, particularly the provision of capable IT services, can be the key element in value proposition in freight forwarder-3PL relationships. The results from this year's study again confirm that the IT gap continues to narrow to some extent

It has been clear for some time that the provision of capable IT services has been the key element of a value proposition in shipper-3PL relationships. Shippers indicate a greater need for activities such as transportation management, warehouse/distribution centre management, visibility, etc., which are mostly execution- and transaction-oriented. In fact, there is a discernible relationship between the propensity of shippers to utilize specific IT-based services and the types of logistics services that are outsourced to 3PLs. IT-based services are of a somewhat lesser priority at present, and it is apparent that these are generally related to processes that are more strategic and customer-oriented [11].

With the growing trend, many enterprises have outsourced their logistics activities to 3PL providers to focus on their core competencies, thereby reducing costs, decreasing investment in non-core activities and improving service. Some 3PLs have recognized this need and adopted innovation practices. Deutsche Post DHL, for example, opened its Innovation Centre in 2006 and defined it as a space for new ideas for forming innovative networks and developing solutions, from prototype to market launch [12]. Logistics outsourcing can reduce non-core business investments [13], and improve logistics performance [14] and client service [15].

To better satisfy shippers' needs, 3PL providers should perform logistics services in a better, faster and cheaper manner for the exporters [16] by synchronizing logistics activities globally with the support of various information technologies. Forming a strategic alliance with a 3PL provider is one of the most effective business strategies for enterprises in China to achieve cost-effective performance and long-term success [14].

A resource-based view suggests that an enterprise can create competitive advantage by accessing the resources and capabilities of its suppliers. 3PL providers have the expertise and resources to perform logistics activities more efficiently and effectively than an inhouse team [16]. They are effective in helping enterprises improve customer service, respond faster, and 
reduce overall logistics costs [17]. Taking a strategic orientation towards 3PL providers enables exporters to realize the full potential of their value-added activities and gain significant competitive advantage over their competitors [16].

Selecting appropriate outsourcing providers is a difficult task due to the fact that outsourcing providers cannot meet all selection criteria simultaneously; they may meet some selection criteria, but may fail in others. Therefore, selecting outsourcing providers may be regarded as a type of multi-attribute decision-making problem [18-20].

Logistics services can definitely be classified as one of the most flexible industries. This industry requires constant and especially quick adaptation to ordering entities to meet the needs of end-users. For external logistics service providers, ever-new and personalized products represent future business activity trends and, at the same time, demanding challenges. Findings from the EU logistics industry defined according to [21] are:

- Approach to client needs. European logistics service providers define the approach, achievement and meeting of client needs as the most important tendency and challenge in the industry;

- Net economy. In the current period of economic stringency, the concept of independence and autonomy of external logistics service providers no longer suffices to achieve efficient business operations. In order to accomplish the goals set, enterprises are forced to integrate upwards and downwards through the entire supply chain. Enterprises have to overcome the mindset of a single market player and replace it with a networking mindset;

- Costs pressures. By approaching the increasingly demanding clients and by providing extremely specific business solutions, the costs of logistics services cannot be as low as they were in the past. Lofvers (idem) concludes that the costs of logistics services account for between $4 \%$ and $6 \%$ of an enterprise's revenues. On the other hand, he further concludes that these costs increase and, for manufacturing enterprises, they can encompass up to $8 \%$ of revenues;

- Shortage of suitable personnel. The research to which Lofvers refers indicates that the main challenge concerning all geographical regions and industries of ordering entities in outsourcing in the coming years will be precisely the availability of a sufficient number of personnel suitably trained in logistics. The shortage of personnel is currently reflected in the level of both operational functions and planning and supervision functions.

A survey which was conducted on a sample of 30 Slovenian enterprises that operate as suppliers in the automotive industry revealed that enterprises that use a system for controlling logistics cost experience fewer disruptions in their business processes in their efforts to satisfy customer demand. These enterprises also display a higher level of integration of business processes [22].

These findings are based on the logistics industry on the EU territory and from 6 years' practical experience in the field of logistics. However, such studies in Slovenia are limited; thus, we had the need to develop a customized questionnaire for the logistics industry field. The questionnaire focused on revealing trends of demand for logistics services, and what the required and desirable outsourcing provider's activities are.

\section{METHODS AND RESULTS}

Data were collected using a web survey methodology. Contacts were provided by the Chamber of Commerce and Industry of Slovenia - a list comprising 5,626 email addresses of member enterprises. All the organizations were invited to participate in the study by filling in a questionnaire.

The questionnaire was sent to the member enterprises at the beginning of 2015. The web survey was active for two weeks. During this time 266 participants completed the questionnaire with an attained response rate of $4.7 \%$. The respondents participated voluntarily and anonymously. The 5-point Likert-type scale questions (strongly disagree - completely agree or completely irrelevant - very important) were focused on logistics services and logistics outsourcing providers' characteristics. The other questions included sector, size, region and a general enterprise overview. The internal consistency indicated a high Cronbach coefficient $\alpha=0.846$, providing us with a reliable measurement instrument.

Data analysis was conducted using IBM SPSS for Windows 22.0. In addition to descriptive statistics, multivariate hierarchical cluster analysis and other bivariate statistics were used. Cluster analysis with the Ward method was used to split the sample of enterprises into heterogeneous groups (Cost, quality \& response and Logistics, environment \& other) based on logistics services and logistics outsourcing provider characteristics. T-statistics was conducted to evaluate statistically significant differences between the two groups of enterprises (Cost, quality \& response and Logistics, environment \& other). The chi-square statistical test was used to test the association between size and the two enterprise groups (Cost, quality \& response and Logistics, environment \& other).

Most of the participants are from organizations from the processing sector (19.9\%), other sectors (14.3\%), motor vehicle sales, the maintenance and repair sector (12.8\%), and from the information and communication sector (11.7\%). Almost half of the respondents are employees of an organization based in Central Slovenia (45.5\%), followed by respondents 
from Upper Carniola (10.5\%). The majority (45.1\%) of the representatives in the sample comprised micro enterprises with fewer than 10 employees, followed by representatives of small enterprises making up 35.2\% (up to 50 employees), while $15.1 \%$ of the respondents represented medium-sized enterprises (up to $250 \mathrm{em}$ ployees) and only $4.6 \%$ large enterprises.

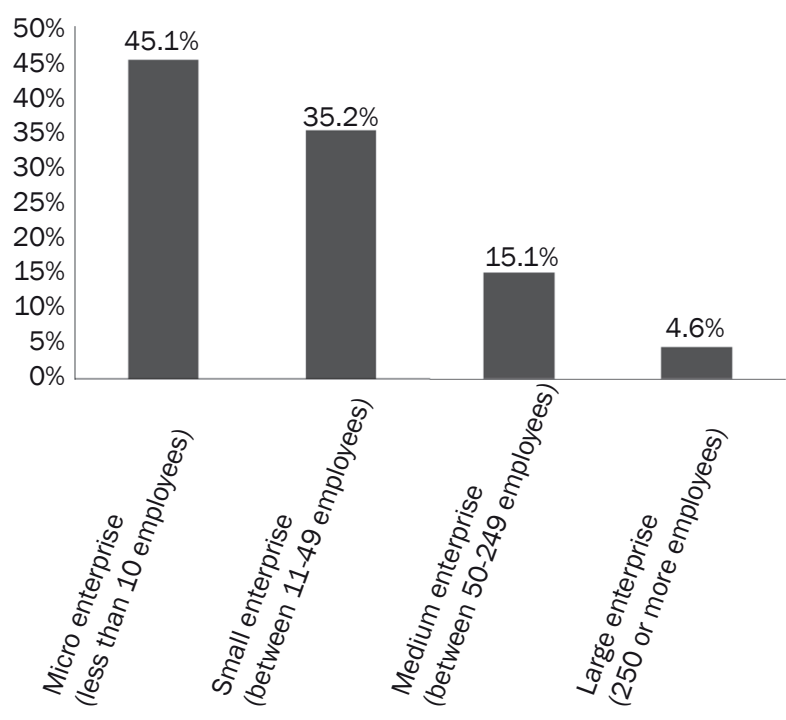

Figure 1 - Enterprise sizes in the sample $(n=266)$

Hierarchical cluster analysis was computed using eight variables dealing with logistics and transport service characteristics that enterprise representatives believed to be more or less useful to their enterprise. Questions regarding logistics and transport service characteristics were included in the 5-point Likert scale to what extent ( 1 = totally unimportant, 5 = very important) the following logistics and transport service characteristics are important to you in cooperation with external providers: cost-effectiveness/affordability, quality of service, swift and efficient response, ability to adapt to the client's process, environmental impact, capacity to provide comprehensive logistics services (supply chain management, commissioning, etc.), logistics supported by a good IT subsystem, distinctive and strong brand provider.

We used the Ward method $(n=266)$ and denoted two homogenous groups according to the average values of logistics service characteristics. The groups comprised:

1) a smaller group (28.7\%), which considered cost, quality and response to be most important;

2) and a larger group (71.3\%), where logistics, environment and other characteristics of logistics services were considered most important.

Based on their size, the enterprises were distributed uniformly within the two established groups. The first group comprised a larger share of large enterprises $(7.3 \%)$ and a smaller share of medium-sized enterprises (9.8\%), while the second group comprised only $2.5 \%$ of large enterprises and $16.0 \%$ of medium-sized enterprises. The differences between the two groups are not statistically significant (chi-square $=2.360$, $p=0.501$ ), confirming the uniformity of distribution between the two groups.

In Figure 2 we can see that the group of enterprises consider all Logistics and transport service characteristics to be of important value; Distinctive and strong brand provider less so; with Environmental impact also playing a lesser role.

The other group of enterprises, on the other hand, emphasized four key points, valuing logistics and

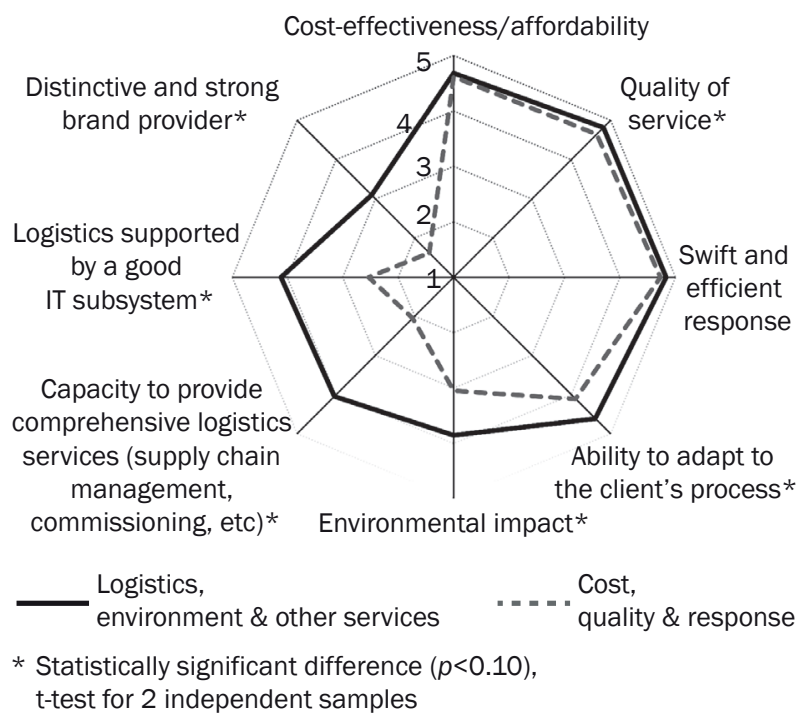

Figure 2 - Average values of the group's Logistics and transport service characteristics (for defining clusters)

Table 1 - Enterprise sizes within the groups

\begin{tabular}{||l|c|c|c|c||}
\hline & $\begin{array}{c}\text { Micro } \\
\text { enterprise (fewer than } \\
10 \text { employees) }\end{array}$ & $\begin{array}{c}\text { Small } \\
\text { enterprise (11-49 } \\
\text { employees) }\end{array}$ & $\begin{array}{c}\text { Medium enterprise } \\
\text { (50-249 employees) }\end{array}$ & $\begin{array}{c}\text { Large enterprise (250 } \\
\text { or more employees) }\end{array}$ \\
\hline \hline $\begin{array}{l}\text { Cost, } \\
\text { quality \& response }\end{array}$ & $43.9 \%$ & $39.0 \%$ & $9.8 \%$ & $7.3 \%$ \\
\hline $\begin{array}{l}\text { Logistics, } \\
\text { environment \& other }\end{array}$ & $42.0 \%$ & $39.5 \%$ & $16.0 \%$ & $2.5 \%$ \\
\hline Total & $42.6 \%$ & $39.3 \%$ & $13.9 \%$ & $4.1 \%$ \\
\hline
\end{tabular}


transport service characteristics, such as cost-effectiveness/affordability, quality of service, swift and efficient response and ability to best adapt to the client's process, with the other characteristics being of less importance.

Next, we were interested in discovering which logistics and transport services the enterprises from the two groups benefited from most? We compared the 5-point Likert-scale question: 'To what extent do you agree ( 1 = strongly disagree, 5 = totally agree) that, in the context of logistics and transport services, your enterprise benefits, or would benefit (in the short-term, medium-term), from one of the following services?'

In Figure 3 we can see that a difference exists between the two groups. Both groups are primarily interested in express freight and shipment services, followed by transport function (planning, organizing, and schedules). The larger group to a greater extent believes that their enterprise could benefit from all of the services, while the smaller group remains focused on two important ones.

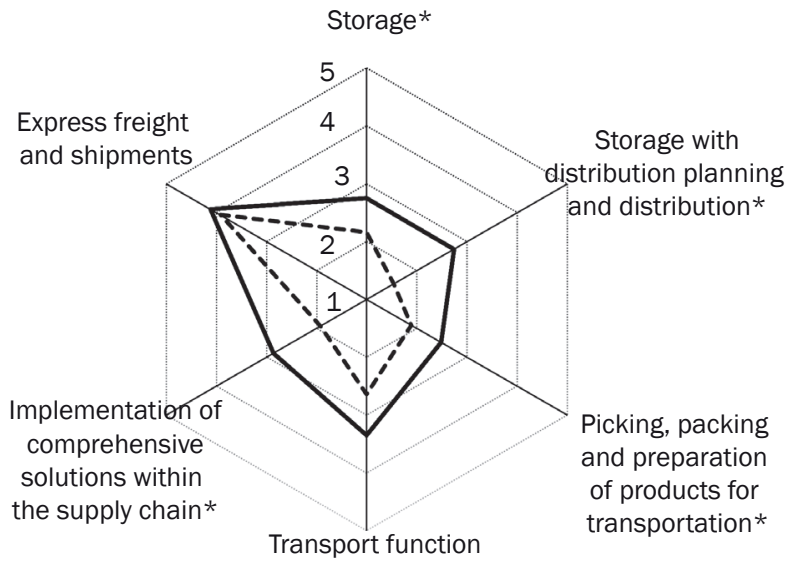

(planning, organizing schedules)*

\footnotetext{
$-\begin{array}{ll}\text { Logistics, } \\ \text { environment \& other services } \quad=--=\text { Cost, } \\ \text { quality \& response }\end{array}$

* Statistically significant difference $(p<0.10)$,

t-test for 2 independent samples
}

Figure 3 - Average values of group's characteristics regarding logistics and transport services

The differences between the two groups of enterprises are statistically significant at the level of $p<0.10$ with regard to all services, except for express freight and shipment.

Experience, price, quality and technology matching are, on the other hand, equally important for both groups of enterprises. Price and quality are the top priorities when choosing a business partner for outsourcing logistics and transport services.

We continued with the group comparison in order to detect which logistics and transport service characteristics are taken into account when an enterprise decides to rely on an outsourced service provider.

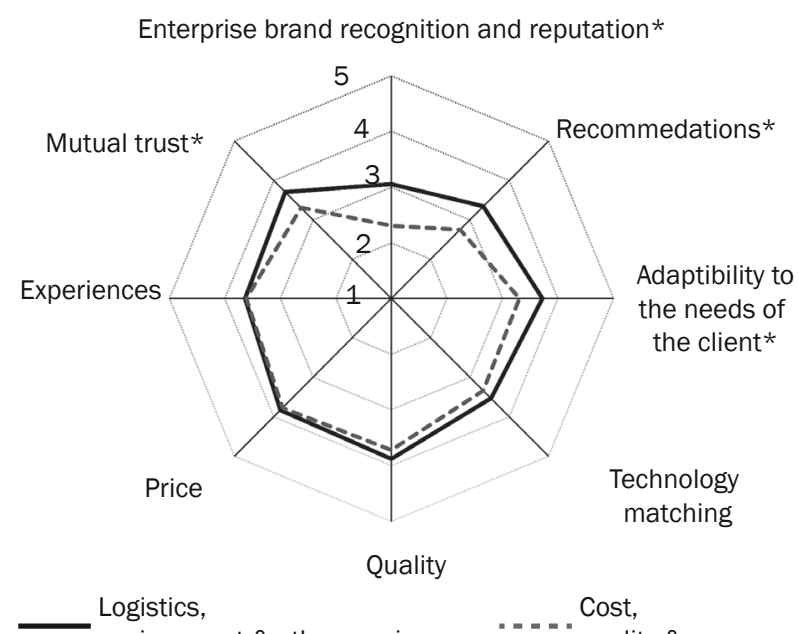

* Statistically significant difference $(p<0.10)$,

t-test for 2 independent samples

Figure 4 - Average values of important characteristics for the group when choosing a business partner to outsource logistics and transport services

At this point we were interested in discovering which characteristics were important when choosing the appropriate business partner to whom the needed services would be outsourced. We used a 5-point Likert-scale question ( 1 = strongly disagree, 5 = totally agree) to compare the importance of characteristics in selecting the appropriate business partner within the two previously established groups.

The differences between the two groups are clear regarding characteristics such as mutual trust, the enterprise's reputation and brand recognition, recommendations, and adaptability to the needs of the client, with agreement on cost, quality and response being statistically significant in the first group.

\section{DISCUSSION AND CONCLUSION}

Based on the results of this research, it can be concluded that the services offered by enterprises for logistics outsourcing can further ensure the required quality level and acceptable prices of those services.

The results and findings of the $19^{\text {th }}$ Annual $3 \mathrm{PL}$ Study show that the most frequently outsourced activities tend to be those that are more transactional, operational and repetitive in nature.

The results of this research predict growth in the branches that have been studied and confirm the prediction of overall economic growth. Due to globalization processes, data availability and more and more accessible communication channels, one cannot underestimate or even exclude the possibility of powerful foreign enterprises entering the field, as their large range of activities enables greater cost-efficiency and the quality required in this field. 
Based on the results of our study, we can confirm that our forecast as the percentage of organizations that currently rely on logistics services from external providers is already $73.9 \%$, and interest continues to grow. As many as $21.3 \%$ of organizations surveyed intend to search for a new partner in logistics services within the next three years; an additional $5.4 \%$ of organizations will transfer their services to external providers for the first time. The logistics services will definitely be affected by factors such as technology, innovation and the transparency of business cooperation.

The research shows that the respondents were least interested in storage and storage with distribution planning; on the other hand, they were very interested in express freight and shipment transport and services, as well as transport function. Regarding IT solutions, the respondents were most interested in renting software with a support guarantee, the implementation of comprehensive solutions adapted to the client, and an e-archive including data security. With this research we have managed to identify a market segment. We particularly wish to emphasize the finding that all respondents have shown an above-average interest in guarantee and data security.

In view of the findings, we advise the logistics service providers to optimize and adapt their distribution channels, which can also be achieved by providers of external services with great effect.

For Slovenian enterprises it is important to continue with customized outsourcing; process coordination, information sharing and market advantages shall be considered as the next step in the development process. In the future, it would be sensible to carry out a similar study in comparable countries (e.g. Croatia, Czech Republic, Slovakia and Serbia) and compare the results.

\section{Dr. KLEMEN KAVČIČ ${ }^{1}$}

E-mail: klemen.kavcic@fm-kp.si

Dr. JANA SUKLAN ${ }^{2}$

E-mail: jana.suklan@fuds.si

Dr. FRANKO MILOST ${ }^{1}$

E-mail: franko.milost@fm-kp.si

${ }^{1}$ Univerza na Primorskem, Fakulteta za management

Cankarjeva 5, 6101 Koper, Slovenija

2 Fakulteta za uporabne družbene študije

Gregorčičeva 19, 5000 Nova Gorica, Slovenija

\section{ZUNANJE IZVAJANJE LOGISTIČNIH AKTIVNOSTI: PRIMER SLOVENIJE}

\section{POVZETEK}

Namen te raziskave je raziskati, kako potekajo aktivnosti zunanjega izvajanja $v$ logistiki, ki je bilo tradicionalno izvedeno $v$ podjetju, ki išče zunanje izvajalce. Raziskava ponuja pregled značilnosti logističnih in prevozniških storitev, ki so pomembne za sodelovanje s ponudniki storitev. Izoblikovani sta bili dve skupini glede na povprečne vrednosti značilnih logističnih storitev. 'Stroški, kakovost in odzivnost' so bolj pomembne za prvo skupino, medtem ko so 'logistika, okolje in sposobnost prilagajanja procesom stranke' pomembni za drugo skupino. Rezultati raziskave, ki je bila opravljena na vzorcu slovenskih podjetij kažejo, da obe skupini predvsem zanimajo hitra dostava in da je razlika le $v$ razumevanju pojma logistika, medsebojnem zaupanju in prepoznavnosti blagovne znamke. Ugotovitve raziskave so pomembne tako za poslovno prakso kot za direktorje podjetij, saj omogočajo boljše razumevanje zunanjega izvajanja v logistiki.

\section{KLJUČNE BESEDE}

zunanje izvajanje logističnih dejavnosti; ponudniki logističnih storitev; oskrbne verige;

\section{REFERENCES}

[1] Tate WL, Ellram LM, Bals L, Hartmann E. Offshore outsourcing of services: an evolutionary perspective. Int J Prod Econ. 2009;120(2):512-524.

[2] Vitasek K, Ledyard M. Vested outsourcing: a better way to outsource. Supply Chain Management Review. 2010;13(6):20-27.

[3] Langley CJ. Third-party logistics study: the state of Iogistics outsourcing. Atlanta, GA: Capgemini Consulting; 2013.

[4] Zacharia ZG, Sanders NR, Nix NW. The emerging role of the third-party logistics provider (3PL) as an orchestrator. J Bus Logist. 2011;32(1):40-54.

[5] Langley JC. Third-Party Logistics - The state of logistics outsourcing 2015. 19th Annual Third-Party Logistics Study [Internet]. 2015 [cited 2015 Oct 10]. Available from: http://www.3PLstudy. com

[6] Ernst \& Young. Outsourcing in Europe: an in-depth review of drivers, risks and trends in the European outsourcing market [Internet]. 2013 [cited 2015 Mar 7]. Available from: http://www.ey.com/Publication/ vwLUAssets/Outsourcing_in_Europe_2013/\$FILE/ EY-outsourcing-survey.pdf

[7] Maloni MJ, Carter CR. Opportunities for research in third-party logistics. Transport J. 2006;45(2):23-38.

[8] Skjoett-Larsen T. Third party logistics - from an interorganizational point of view. Int J Phys Distrib Logist Manag. 2000;30(2):112-27.

[9] Liu C, Huo B, Liu S, Zhao X. Effect on information sharing and process coordination on logistics outsourcing. Ind Manage Data Syst. 2015;115(1):41-63.

[10] Hsiao HI, Vorst JG, Kemp RGM, Omta, SWF. Developing a decision-making framework for levels of logistics outsourcing in food supply chain networks. Int J Phys Distrib Logist Manag. 2010;40(5):395-414.

[11] Jayanth J, Keah-Choon T. Supply chain integration with third-party logistics providers. Int J Prod Econ. 2010;125(2):262-271.

[12] Deutsche Post DHL. Innovationcenter [homepage on the Internet]. 2012. Available from: http:// dsi.dhl-innovation.com/en/innovationcenter/indexS4

[13] Razzaque MA, Sheng CC. Outsourcing of logistics functions: a literature survey. Int J Phys Distrib Logist Manag. 1998;28(2):89-107. 
[14] Chen H, Tian Y, Ellinger AE, Daugherty PJ. Managing logistics outsourcing relationship: an empirical investigation in China. J Bus Logist. 2010;31(2):278-299.

[15] Krakovics F, Leal J, Mendes P, Lorenzo R. Defining and calibrating performance indicators of a $4 \mathrm{PL}$ in the chemical industry in Brazil. Int J Prod Econ. 2008;115(2):502-514.

[16] Yeung K, Zhou H, Yeung ACL, Cheng TCE. The impact of third-party logistics providers' capabilities on exporters' performance. Int J Prod Econ. 2012;135:741-753.

[17] Boyson S, Corsi T, Dresner M, Rabinovich E. Managing effective third-party logistics relationships: what does it take? J Bus Logist. 1999;20(1):73-100.

[18] Buyukozkan G, Cifci G. A novel hybrid MCDM approach based on fuzzy DEMATEL, fuzzy ANP and fuzzy TOPSIS to evaluate green suppliers. Expert Systems with Applications. 2012;(39):3000-3011.
[19] Chang SI, Yen C, Ng SP, Chang WT. An analysis of IT/ IS outsourcing provider selection for small- and medium-sized enterprises in Taiwan. Information \& Management. 2012;(49):199-209.

[20] Chen LY, Wang TC. Optimizing partners' choice in IS/ IT outsourcing projects: the strategic decision of fuzzy VIKOR. Int J Prod Econ. 2009;(120):233-242.

[21] Lofvers, M. Trends \& strategies in logistics and SCM. 2013. [cited 2015 Mar 9]. Available from: http://www. supplychainmovement.com/trends-strategies-in-logistics-and-supply-chain-management

[22] Škerlič S, Muha R. The importance of systems for controlling logistics costs in the supply chain: a case study from Slovenian automotive industry. Promet-Traffic\&Transportation. 2016;28(3):299-310. 